\title{
The potential of complex challenges in undergraduate research to stimulate transformative learning
}

\author{
Patric Wallin \\ Department of Education and Life-long learning, NTNU, Trondheim, Norway \\ Engineering Education Research, Chalmers University of Technology, Gothenburg, Sweden
}

\begin{abstract}
In the present study, I describe and evaluate the transformative learning potential of authentic research projects that engage students in a course on tissue engineering at Chalmers University of Technology. Through the use of weekly reflective diaries and interviews, I explore how students change their perspective on what learning means to them and the purpose of higher education. Based on the empirical data and scientific literature, I discuss complex challenges as one emerging and deciding factor that helps students to have transformative learning experiences. At the end, some general advice will be provided on how educators can approach the integration of complex challenges into their own courses and settings.
\end{abstract}

\section{INTRODUCTION}

For working engineers, it is crucial to be able to adapt to constantly changing problems, contexts, and technologies in our knowledge-based society (Jonassen, Strobel, \& Lee, 2006). Therefore, it is important that engineering students build the capacity to learn, adapt, and develop approaches constantly, as well as advance their ability to engage in lifelong learning (Kenny et al., 1998). It is this capacity and development that will enable future engineers to aid society to work towards solving the 17 sustainability goals to transform our world (www.un.org/sustainabledevelopment/), among other things. In order to help students to become lifelong learners and promote active learning, studentcentered and inductive teaching methods have become more widely spread in engineering education during the last two decades (Prince \& Felder, 2006). These methods include inquiry-based learning, where applications and real-life examples are at the center of the learning experience, and where students are encouraged to take a larger responsibility for their own learning compared to traditional teaching (Kuh, 2008).

One particular way to implement inquiry-based learning in higher education is through undergraduate research (UR), which allows students to become part of ongoing research activities at the university (Sadler \& Mckinney, 2010). In UR, students work together with doctoral students, post-doctoral fellows, and permanent faculty members on authentic research problems, where they investigate questions with unknown answers (Brew, 2013). Traditionally, UR has been in the form of summer internships (Lopatto, 2009), but has more recently become an integral part of a range of courses at universities all over the world (Corwin, Graham, \& Dolan, 2015).

The nature of the inquiry that students engage in and the fact that the answers to their questions are unknown to everyone challenges the students. It requires them to change their view on knowledge and learning, as they need to see knowledge as something that they actively construct and co-constructed, and realize that it is this process that helps them to learn (Bråten \& Strømsø, 2005; Hofer \& Pintrich, 2015). These conceptual changes in how students think about knowledge and learning are important parts of higher education (Lahtinen \& Pehkonen, 2012) and are often summarized as part of their intellectual development (Felder \& Brent, 2004). UR provides students with a student-centered learning experience that challenges them, and promotes students' intellectual development by giving them the chance to become authors of their own learning and development in what Magolda (2007) calls self-authorship: "the internal capacity of a student to define his/her own belief system, identity, and relationships" (p. 69).

Students' intellectual development and self-authorship are coupled to what Biesta (2009) called the socialization function of education that helps students to become part of a sociocultural context and grow as persons. This is in contrast to the qualification function of education that focuses on the acquisition of knowledge, skills, and dispositions that qualify students for doing something (Biesta, 
2009). For future engineers to be able to engage in lifelong learning, it is important to balance the socialization and qualification function of education. Transformative learning theory offers an interesting perspective in this respect, and emphasizes the development of a "more critical worldview as we seek ways to better understand our world" (Taylor, 2008) as a crucial part of adult learning. Transformative learning theory conceptualises learning as a perspective transformation. It is through this transformative process that students change their mental and cognitive structures of assumptions through which they understand their experiences. This is what Mezirow (1997) referred to as frames of reference. In other words, transformative learning goes beyond the acquisition of factual knowledge; it changes how students experience the world around them and the identities they develop (Illeris, 2014).

As pointed out by Ballen et al. (2017, p. 1): "an increase in research revealing the positive effects of [course-based undergraduate research experiences] for science majors, less work has specifically examined whether nonmajors are impacted in the same way". I would add that it is also important to broaden the scope of what potential effects UR has on students and take a closer look at how UR can help students to transform their perspective on learning and education. By using transformative learning theory as a lens to look at UR experiences, it is possible to better understand the effects that these experiences have on students' learning, and what students learn beyond the skills and knowledge needed in research, as well how to integrate the ideas and concepts of transformative learning theory into practice.

With this in mind, I explore, in the present study, the transformative learning potential of authentic research projects and take a closer look at: 1) What do students describe as the triggers for transformative learning?, and 2) How do students' perspectives on learning, education, and themselves change? These two questions will be studied through the use of reflective diaries and interviews in a qualitative research approach. Based on the empirical support, I will discuss the potential of UR to promote transformative learning, the importance of risks and challenges in higher education, and provide some reflective pointers to adapt these ideas to other settings.

\section{STUDY CONTEXT AND DESIGN}

The context for this study is a master-level course (15 ECTS-credits) on tissue engineering that runs over a five-month period at Chalmers University of Technology, Gothenburg, Sweden. The main stated learning intentions for the students in this course are to:

1) Gain an overview of the tissue engineering field

2) Understand the fundamental science and technology that form the building blocks of the field

3) Develop research competencies relevant to the field and a research identity

In addition, an overall aim of the course is to offer students the possibility to work together with researchers on authentic problems and become part of the research community. The tissue engineering course consists of lectures, article review sessions, and a research project to promote inquiry-based learning.

In the research project, students work in groups of four to six over the entire five-month period of the course, together with a mentor. All projects are directly coupled to on-going research at the university, and the students experience three types of authenticity through the projects:

1) Authentic problems that are of broad relevance (Ballen et al., 2017) to the scientific community and where the answer is unknown to everyone.

2) Authentic physical environments when working in research laboratories rather than student laboratories ${ }^{1}$.

3) Authentic social environments through their interaction with their mentor, as well as by being part of the larger research group of the mentor.

\footnotetext{
${ }^{1}$ This is in contrast to many other course-based undergraduate research experiences, where students regular work in student laboratories (Auchincloss et al., 2014), as I and colleagues have discussed previously (Wallin et al., 2017).
} 
Figure 1 shows an overview of two different projects with their aims, setups, and results. The project titles and aims are chosen and developed by the students themselves, and results are taken directly from the students' final reports. The strong coupling to the mentors' own research means that students' findings often influence the mentors' research work directly and are regularly integrated into publications. For example, the developmental work and results from the project in 2012 were used as important input for the "Skeletal muscle differentiation in 3D capillary alginate hydrogels" project in 2014, which later was used in an article published in Food Hydrocolloids (Schuster, Wallin, Klose, Gold, \& Ström, 2017). In general, one of the aims is that all the tissue engineering course projects should have the potential to be published in peer-reviewed journals with some additional work. The objective of the project is, however, not only to generate publishable results and to gain a deeper understanding of the outcomes of research, but also to experience research as it is conducted to gain an understanding of the scientific process. For a more detailed description of the course see (Wallin, Adawi, \& Gold, 2017; Wallin, Gold, \& Adawi, 2013).

\begin{tabular}{|c|c|c|c|}
\hline & Project title & Project aims & Setup and Results \\
\hline $\begin{array}{l}\mathbf{N} \\
\mathbf{N}\end{array}$ & $\begin{array}{l}\text { Skeletal Muscle Tissue } \\
\text { Engineering }\end{array}$ & $\begin{array}{l}\text { Finding the optimal serum concentration for } \\
\text { differentiation of myoblasts } \\
\text { - Development of a microfluidic platform } \\
\text { that combines gradients and micro grooved } \\
\text { surfaces } \\
\text { - Optimization of cell culture protocols } \\
\text { - Formation of serum gradients with the } \\
\text { help of a microfluidic chip } \\
\text { - Differentiation in response to the gradient }\end{array}$ & $\begin{array}{l}\text { Difierentited muscle cells culturued in a } \\
\text { petri dish with } 10 \% \text { horse serum }\end{array}$ \\
\hline $\begin{array}{l}+ \\
\tilde{N}\end{array}$ & $\begin{array}{l}\text { Skeletal muscle } \\
\text { differentiation in 3D } \\
\text { capillary alginate } \\
\text { hydrogels }\end{array}$ & $\begin{array}{l}\text { Develop a culture system for muscle cells based on } \\
\text { capillary alginate gels } \\
\text { - Formation of stable and sterile capillary alginate } \\
\text { gels } \\
\text { - Test modifications of alginate gels to improve the } \\
\text { cell-matrix interactions } \\
\text { - Design and construction of a perfusion bioreactor } \\
\text { - Evaluate the } 3 D \text { cell culture system with the gels } \\
\text { and the bioreactor }\end{array}$ & 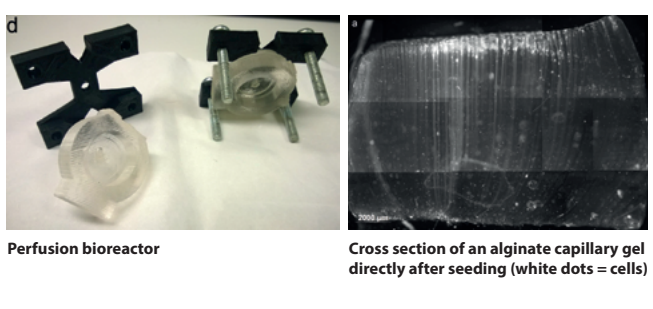 \\
\hline
\end{tabular}

Figure 1: Overview of two different projects in the tissue engineering course

The students' learning experiences and potential transformations were explored using a qualitative research approach based on the diary-interview method (Zimmerman \& Wieder, 1977). It is through the combination of diaries and interviews that students' experiences can be studied over time and in-depth by building on the strength of both diaries and interviews. The diaries are a writing tool for students that can help them in their reflection process and promote metacognitive skills by providing them with a medium to write down their thoughts (Walker, 2006). Careful prompt design stimulates students to actively reflect upon both the content and their own learning behavior (Jarvis, 2001). In this study, the approach was used with one project group. Student participation in writing the diaries and participating in the interviews was voluntary, and all four students in the group gave their informed consent that their diaries and interviews could be used as research data. The students were asked to write and submit weekly reflective diaries around specific prompts. The prompts alternated between general topics like "This weeks challenges" in even weeks and topics focused on the different project phases in uneven weeks. In week three for example, the prompt was "Learning from the scientific literature", and in week nine "Working in the lab". Each prompt was combined with a number of questions to further stimulate the students' reflections, for example:

\section{This week's challenge}

What was the greatest challenge this week? Why was it challenging? How did you approach this challenge? In what way was it important for your progress? Would you approach it in the same way again or differently? 
A complete list with all prompts and a more detailed description of the design and implementation process of the reflective diaries are available in Wallin et al. (2016).

Using the students' weekly diaries as a research tool provided rich continuous data, and it was possible to follow the students during the entire project. To clarify and deepen the understanding of certain aspects of the students' experiences, interviews were used at the end of the course. In the semi-structured interviews, small sections of the students' reflective diary entries were utilized as entry points to help them to recall situations, reflect more deeply upon certain aspects, and take a holistic stance towards their experience. The main topics that emerged from the reflective diaries and that were taken up in the interviews were: the work with the scientific literature, the project focus and structure, science in practice, summarizing and generating meaning from experimental data, and the student's professional development. The interviews lasted between 50 and 90 minutes and were all audio-recorded and transcribed for later analysis.

For the initial analysis, the data from the reflective diaries and interviews was pooled together and a general inductive approach (Thomas, 2006) was used to find emergent themes. The themes that emerged were learning to navigate the field, learning to do real research, and learning to work with others. In a previous study (Wallin et al., 2017), I used these themes to investigate the success factors of the tissue engineering course: a holistic approach to linking teaching and research, engaging students in the whole inquiry process, and situating authentic problems in an authentic physical and social context. In the study presented here, I take one step back and look at the more fundamental aspects of the students' learning experience and the transformative potential of the tissue engineering course. For this purpose, I re-analysed the pooled data and used intellectual development and transformative learning as sensitizing concepts (Braun \& Clarke, 2006) to take a holistic approach to the students' learning experiences across the original categories. The data was read repeatedly to identify in what ways students talk about their own approaches to learning and higher education, as well as how they conceptualize knowledge. Through an iterative analysis process, it was possible to explore the transformative learning potential of authentic research projects and take a closer look at how students change their perspectives on what learning means to them and the purpose of higher education.

\section{RESULTS}

From the diaries and interviews, it becomes clear that students not only learn something about tissue engineering, research, and working in a group during the tissue engineering course, but that some students reconsider what learning actually means to them and change their view on higher education itself. The results are structured around three themes: Being challenged being lost, Learning for life, and Becoming a researcher. In the first theme, I will take a closer look at what potentially triggers students' transformative learning and how students experience this initial phase. In the second and third theme, I will explore how students change their views on learning and education, and how the UR experience influences their self-perception, respectively. Students are referred to by pseudonyms: Julia, Tim, Anna, and Sara.

\section{Being challenged - being lost}

The tissue engineering project puts students into a new situation, where they work on authentic research projects. The students need to define their own questions, think about what approaches they want to use to answer them, design their experiments, collect and analyze their data, discuss their results in the light of the scientific literature, and summarize their 
findings in a final report and oral presentation. In other words, the students experience what it means to be a researcher and go through all stages of the scientific process (Pedaste et al., 2015). In contrast to many of their previous educational experiences, there are no right or wrong answers; there is not even a question at the start.

This unfamiliar learning experience is often challenging for the students, as they are unsure what to do. Tim reflects in one of his diary entries on how challenging it is to define all the details of a large project. He feels that in many other situations he relies on other people, like teachers and administrators, to define his learning environment and make decisions for him, but that the tissue engineering project helps him to be more independent and learn how to learn:

This detail work is still challenging and I think it is something one can easily forget while studying. Sure, we plan our own future and academic progress but we sometimes hand these duties over to the representatives at the university. Such that we get a laid-out learning schedule and have some choices along the way. Therefore, it is once again a nice experience to make this self-assessed learning and basically "learn to learn", once again.

Reflective diary Tim

In a similar way, Julia describes how she and her group members felt lost at the beginning of the project, because they had so much freedom and did not know how to approach the situation. In the interview however, she also explains that being lost at the beginning was important and that the group got used to it. When she looks back at the course she feels that this experience is important and often missing in other courses:

In the beginning, it felt to us that we had too much freedom, because we did not really know what to do and where to go. We did not know the [scientific field] exactly, so we did not know what we wanted to achieve. So, we felt a bit lost, because it was a bit too open. At the same time, that is good, because you are never in that situation in other courses, because there you have clear instructions to do this and this and this to reach this goal. We got used to [the freedom in this course] over time and in the end we really liked it.

Interview with Julia

\section{Learning for life}

While the tissue engineering course creates a situation for students that is initially new, difficult, and challenging, the students appreciate it once they have overcome their first resistance and see it as an opportunity. As Julia stated: "We got used to [the freedom in this course] over time and in the end we really liked it." It is through the process of accepting the challenges and seeing the opportunities that students also start to question and reconsider more fundamental assumptions about education that they hold. Most students in the course have been growing up with the notion that grades are a central element of education and that good grades are important to progress through the education system to eventually get a job. In the tissue engineering course, they start to question the importance of grades and discover other motivations to work on the projects. Anna writes in her final diary entry about how much she appreciates the project work and how it is much more motivating than exams:

I think working in project form is so great because you really have to dig for relevant information, read a lot and focus on the problem to be solved. Better motivation than studying for an exam!

Reflective diary Anna

Julia, on the other hand, points out that she is now much more comfortable to ask questions. Through the course, she has started to see discussions as important learning experiences rather than assessment points where she is judged: 
I have become more comfortable with asking questions and discuss things. It is now more important for me to learn from it, rather than thinking this is a stupid question and do not ask at all. I realized that nobody knows everything, and people are not there to judge each other, but they are there to exchange experiences and knowledge.

Interview with Julia

Tim explains that grades normally play an important role, but that it was different in the tissue engineering course. He points out that the learning itself was the most important part, which is difficult to measure in grades, but something that nobody can take that away from him:

Of course academic results are important, but in this special case it is not the [grades] that are important but the knowledge I can gather and keep for myself. Nobody can take that away from me... We gained so much experience. The amount of experience is hard to measure.

Reflective diary Tim

This shift in focus from learning for grades towards learning to gain experience and knowledge means that these students begin to see their own education as something more than just an obstacle than one needs to complete to get a job. They appreciate learning itself and want to understand the world around them, instead of focusing mainly on assessment and grades. They transform their perspective on the value of learning and what higher education is for.

\section{Becoming a researcher}

The students' perspective change on the value of learning and what higher education is for is also closely coupled to a change in how students see and conceptualize themselves. At the beginning of the tissue engineering course, students often see themselves predominantly as students that need to follow certain instructions and procedures imposed upon them by the teacher. Sara explains in one of her last reflective diaries how she at the beginning felt like a student working on an assignment, but that through the engagement and work in the course she became a researcher. For her the course helped her to grow up and do something important rather than just repeating others' work:

\footnotetext{
When I started in the course, I felt more like a student. It was more like an assignment that I had to do, but later on when we started working in the lab and search[ing] literature to define our own project, coming up with our own ideas, it felt like being a researcher. It is like growing up, you become more confident. It is not just trial and error and repeating others work.
}

Reflective diary Sara

Tim also saw himself as a researcher at the end of the course. He emphasized that the transformation from being a student to becoming a researcher and working on the project was not always easy, but he also pointed out that he enjoyed the process and that it felt good to go through it:

I do see myself as a researcher. On the one hand, there is one thing that I have to point out: it was not always easy to do this project . . . one had to put a lot of passion into it. But the fact is that it still pleased me in a way, I felt like home. It just gave me a good feeling...

Reflective diary Tim

Taking into account that these are first-year master students, the transformation from being a student towards becoming a researcher, or more generally speaking a professional, is an important step in students' development and something that the students enjoy and value. The students explain that it is through embracing the challenges and working on the authentic projects that this transformation is happening. 


\section{DISCUSSION}

The ability to follow students over time through the weekly diaries is of great value, as it opens the possibility to see their development and transformation. This was important in order to explore the transformative learning potential of authentic research projects and gain a deeper understanding in what ways students change their perspective on what learning means to them and the purpose of higher education. The small scale of this study does not allow for any generalization or to approach the question of how common this transformation process is. However, the depth in the students' diaries and interviews, as well as the fact that the method presented here allowed the continuous monitoring of students' reflections, are of great value to see the potential that UR has and what kind of developments and transformations are possible. Keeping the limitations in mind, the discussion is focused around the potential of UR to promote transformative learning, the importance of risks and challenges in higher education, and how these ideas might be used in other settings.

Reading the students' diaries and listening to them in the interviews allows us to better understand how students conceptualize their own learning and education. It becomes clear that being challenged at the beginning of the project is an important aspect of the learning and development process that the students go through. It is this initial phase where the students feel lost that acts as a trigger for them and that starts a process through which they potentially will reconsider their approaches to learning and alter their self-perception from being students towards being researchers. By reconsidering their approaches to teaching and learning, the teachers involved in the tissue engineering course moved away from providing ready-made pieces of knowledge that are later tested in exams with clear answers and grades that measure progress, towards empowering students to drive scientific inquiries in a self-regulated way.

UR offers an interesting way to provide students with complex challenges and give them the opportunity to work on projects, where they need to define their own questions and develop their own answers. The students describe that they experience these complex, potentially disruptive, challenges as a key element for their own learning and development in the tissue engineering course. It is through their involvement in research, an authentic and central activity at the university (Jenkins \& Healey, 2009), that students can realize that the university is more than a place to get a degree from. As Tim pointed out, the course helped him how to learn once again. Throughout the diaries, it is possible to see how the students change their perspective on the value of learning and take an important step towards fully regulating their own learning, which is a key factor in being able to engage in lifelong learning (Muis, 2007). This helps students to be prepared for a world that is constantly changing, or as Nilson (2013) put it: "only lifelong learners will be able to keep up with the explosive growth of knowledge and skills in their career and to retool into a new career after their previous one runs its course". The transformative learning experiences that the students describe in this study help them to become the author of their own learning and development (Magolda 2000 \& Magolda 2001), and UR is a trigger for students to engage in this type of self-authorship. The students in the tissue engineering course start to see learning as an active process, where knowledge is constructed and co-constructed, which is an important pre-requisite to fully profit from student-centered teaching (Bråten \& Strømsø, 2005).

Engaging students in on-going research projects, like in the tissue engineering course, is a risk and from long experience with the course I know that things do go wrong sometimes, but at the same time it creates possibilities. It is important that both teachers and students alike are willing to take certain risks and commit themselves to a course, where things are not fully defined and set from beginning, but where the experiences made during the course are of 
central interest. The students in the tissue engineering course start to realize that nobody knows everything and that being uncertain and lost at the beginning is ok. In other words, the students in this study were able to accept the risks of the course and overcome the challenges that they met on their way. Bieste describes in his book "Beautiful Risk of Education" (2013) the importance of opening up the possibility that students and teachers can walk away from a course with having gotten nothing out of it. By taking this risk, there is at the same time the chance that both have a transformative learning experience "that takes you and that student to new places or new ways of thinking and new models of imitation or you name it in terms of what could come out of it" (Collier \& Friend, 2016).

In more general terms, Bjork (1994) has coined the term desirable difficulties as a way to describe difficulties in learning tasks that can help students to improve their long-term learning and help them to better understand and use what they have learned. Taking this idea further, the disruptive nature of the complex challenges and the strong contrast to previous experiences in education stimulates students to question and reconsider their own frame of reference (Illeris, 2014; Moore, 2005). In this type of transformative learning experiences students will be in a transition state, where their old frame of reference is rejected, but the new one is not yet fully in place (Meyer \& Land, 2005). It is therefore important to not only expose students to complex challenges and confuse them, but provide the necessary scaffolding that helps them to progress and develop (English \& Kitsantas, 2013). In this type of scaffolding, students learn through the interaction with a knowledgeable person that helps them in their development process and gradually reduces their support as the student becomes more independent (Yorke, 2003). While scaffolding can be provided through different approaches, creating a learning environment where students feel safe is a core component of the process (Dolan \& Johnson, 2009; Palmer, Hunt, Neal, \& Wuetherick, 2015).

Creating a save learning environment is particularly important as neoliberal discourses have reshaped the educational landscape and put a strong emphasis on individualism, competition, and assessment (Giroux, 2002; Harvey, 2005). While higher education institutions rightfully place more and more emphasis on student-centered teaching, neoliberal discourses act as counter force that limits students' ability to engage in self-authorship and experience the socialization function of education, by putting a strong emphasis on the qualification function of education (Olssen \& Peters, 2005). The type of learning that the students voice in this study goes beyond the specific context of a course and is concerned with the overall academic development of students. While the tissue engineering part of the course provides the context and situates the UR experience, the learning is not bounded by this context and is concerned more broadly with the very action of learning and higher education itself. This change in frame of reference regarding what learning means to them and what higher education is for is an important step for students in their intellectual development (King \& Magolda, 1996).

Providing students with opportunities for this type of transformative learning is particular important in engineering and science education, as some studies show that students hold more naïve ideas about learning and the purpose of education in these fields (Felder \& Brent, 2004). It is important that we, as teachers of science and engineering, continue to develop and reconsider our teaching approaches and broaden the scope of higher education in these fields to go beyond merely focusing on facts, principles, and procedures presented in a dualistic mode (Wankat, 2002). Based on the empirical data in this study and the literature on transformative learning, I argue that using the example of the tissue engineering course as an inspiration and reflecting upon the pointers below can help teachers to reconsider their teaching approaches and find their own ways to create opportunities for transformative learning. 


\section{Reflective pointers:}

Defining tasks:

- What questions can I ask in my course where there are many different equally right answers or where the answers are unknown?

- How can I use these questions to describe complex challenges that students can work on?

\section{Creating environments:}

- What risks am I taking in this course? And what risks are students expected to take?

- How can I create a learning environment where the students feel safe to take these risks?

\section{CONCLUSION}

In conclusion, this study exemplifies the potential of UR to stimulate transformative learning, where students change their perspective on learning and the purpose of higher education, as well as advance their self-perception from being students towards becoming researchers. A key element to create this type of transformative learning opportunity is to provide students with complex challenges and acknowledge the risks that teachers and students take in creating new learning experiences. The reflective pointers provided here can be seen as a starting point for teachers to think and reflect upon their own teaching approaches and potentially reconsider some of their approaches.

\section{ACKNOWLEDGMENTS}

I am deeply indebted to all the students in this study for sharing their thoughts and experiences through the reflective diaries and interviews. I would also like to thank Tom Adawi for the great collaboration and his thoughtful comments on this work.

\section{REFERENCES}

Auchincloss, L. C., Laursen, S. L., Branchaw, J. L., Eagan, K., Graham, M., Hanauer, D. I., ... Dolan, E. L. (2014). Assessment of course-based undergraduate research experiences: a meeting report. CBE Life Sciences Education, 13(1), 29-40.

Ballen, C. J., Blum, J. E., Brownell, S., Hebert, S., Hewlett, J., Klein, J. R., ... Cotner, S. (2017). A call to develop course-based undergraduate research experiences (CUREs) for Nonmajors courses. CBE Life Sciences Education, 16(2), 1-7.

Biesta, G. J. J. (2009). On the weakness of Education. Philosophy of Education, 354-362.

Biesta, G. J. J. (2013). Beautiful Risk of Education. New York, NY: Routledge Taylor \& Francis Group.

Bjork, R. A. (1994). Memory and metamemory considerations in the training of human beings. In J. Metcalfe \& A. P. Shimamura (Eds.), Metacognition: Knowing about knowing (pp. 185-205). Cambridge, MA: The MIT Press.

Bråten, I., \& Strømsø, H. I. (2005). The relationship between epistemological beliefs, implicit theories of intelligence, and self-regulated learning among Norwegian postsecondary students. British Journal of Educational Psychology, 75(4), 539-565.

Braun, V., \& Clarke, V. (2006). Using thematic analysis in psychology. Qualitative Research 
in Psychology, 3(2), 77-101.

Brew, A. (2013). Understanding the scope of undergraduate research: A framework for curricular and pedagogical decision-making. Higher Education, 66(5), 603-618.

Collier, A., \& Friend, C. (2016). Questioning Learning. Hybrid Pod, (Episode 9).

Corwin, L. A., Graham, M. J., \& Dolan, E. L. (2015). Modeling course-based undergraduate research experiences: An agenda for future research and evaluation. CBE Life Sciences Education, 14(1), 1-13.

Dolan, E., \& Johnson, D. (2009). Toward a Holistic View of Undergraduate Research Experiences: An Exploratory Study of Impact on Graduate/Postdoctoral Mentors. Journal of Science Education and Technology, 18(6), 487-500.

English, M. C., \& Kitsantas, A. (2013). Supporting student self-regulated learning in problem- and project-based learning. Interdisciplinary Journal of E-Learning and Learning Objects, 7(2), 128-150.

Felder, R. M., \& Brent, R. (2004). The Intellectual Development of Science and Engineering Students. Part 1: Models and Challenges. Journal of Engineering Education, 93(4), 269-277.

Giroux, H. (2002). Neoliberalism, Corporate Culture , and the Promise of Higher Education : The University as a Democratic Public Sphere. Harvard Educational Review, 72(4), 425-464.

Harvey, D. (2005). A Brief History of Neoliberalism. New York, NY: Oxford University Press, Inc.

Hofer, B. K., \& Pintrich, P. R. (2015). The Development of Epistemological Theories: Beliefs About Knowledge and Knowing and Their Relation to Learning. Review of Educational Research, 67(1), 88-140.

Illeris, K. (2014). Transformative Learning and Identity. Journal of Transformative Education , 12(2), 148-163.

Jarvis, P. (2001). Journal writing in health education. New Directions for Adult and Continuing Education, 2001, 79-86.

Jenkins, A., \& Healey, M. (2009). Developing the student as a researcher through the curriculum, 1-5.

Jonassen, D., Strobel, J., \& Lee, C. B. (2006). Everyday Problem Solving in Engineering: Lessons for Engineering Educators. Journal of Engineering Education, 95(2), 139-151.

Kenny, S. S., Alberts, B., Booth, W. C., Glaser, M., Glassick, C. E., Ikenberry, S. O., ... Yang, C. N. (1998). Reinventing undergraduate education: A blueprint for America's research universities. (The Boyer Commission on Educating Undergraduates in the Research University, Ed.). New York, NY: Stony Brook.

King, P. M., \& Magolda, M. B. B. (1996). A Developmental Perspective on Learning. Journal of College Student Development, 37(2), 163-173.

Kuh, G. D. (2008). High-Impact Educational Practices. Washington, DC: Association of American Colleges and Universities.

Lahtinen, A.-M., \& Pehkonen, L. (2012). "Seeing things in a new light": conditions for changes in the epistemological beliefs of university students. Journal of Further and Higher Education, 9486(October 2014), 1-19. 
Lopatto, D. (2009). Science in Solution: The impact of undergraduate research on student learning. Tucson, AZ: Research Corporation for Science Advancement.

Magolda, M. B. B. (2007). Self-authorship: The foundation for twenty-first-century education. New Directions for Teaching and Learning, 2007(109), 69-83.

Meyer, J. H. F., \& Land, R. (2005). Threshold concepts and troublesome knowledge (2): Epistemological considerations and a conceptual framework for teaching and learning. Higher Education, 49(3), 373-388.

Mezirow, J. (1997). Transformative Learning: Theory to Practice Transformative Learning Theory. Transformative Learning (Mezirow, (74), 5-12.

Moore, J. (2005). Is Higher Education Ready for Transformative Learning?: A Question Explored in the Study of Sustainability. Journal of Transformative Education, 3(1), 76-91.

Muis, K. R. (2007). The Role of Epistemic Beliefs in Self-Regulated Learning. Educational Psychologist, 42(3), 173-190.

Nilson, L. B. (2013). Creating Self-Regulated Learners: Strategies to Strengthen Students' Self-Awareness and Learning Skills. Sterling, VA: Stylus Publishing, LLC.

Olssen, M., \& Peters, M. A. (2005). Neoliberalism, higher education and the knowledge economy: from the free market to knowledge capitalism. Journal of Education Policy, 20(3), $313-345$.

Palmer, R. J., Hunt, A. N., Neal, M., \& Wuetherick, B. (2015). Mentoring, Undergraduate Research, and Identity Development: A Conceptual Review and Research Agenda. Mentoring \& Tutoring: Partnership in Learning, 1267(April 2016), 1-16.

Pedaste, M., Mäeots, M., Siiman, L. a., de Jong, T., van Riesen, S. a. N., Kamp, E. T., ... Tsourlidaki, E. (2015). Phases of inquiry-based learning: Definitions and the inquiry cycle. Educational Research Review, 14, 47-61.

Prince, M., \& Felder, R. (2006). Inductive Teaching and Learning Methods: Definitions, Comparisons, and Research Bases. Journal of Engineering Education, 95(2), 123-138.

Sadler, T. D., \& Mckinney, L. (2010). Scientific Research for Undergraduate Students: A Review of the Literature. Research and Teaching, 39(5), 43-49.

Schuster, E., Wallin, P., Klose, F. P., Gold, J., \& Ström, A. (2017). Correlating network structure with functional properties of capillary alginate gels for muscle fiber formation. Food Hydrocolloids, 72, 210-218.

Taylor, E. W. (2008). Transformative learning theory. New Directions for Adult and Continuing Education, 2008(119), 5-15.

Thomas, D. R. (2006). A General Inductive Approach for Analyzing Qualitative Evaluation Data. American Journal of Evaluation, 27(2), 237-246.

Walker, S. E. (2006). Journal writing as a teaching technique to promote reflection. Journal of Athletic Training, 41(2), 216-221.

Wallin, P., Adawi, T., \& Gold, J. (2016). Reflective diaries - A tool for promoting and probing student learning. In 12th International CDIO Conference. Turku, Finland. 
Wallin, P., Adawi, T., \& Gold, J. (2017). Linking teaching and research in an undergraduate course and exploring student learning experiences. European Journal of Engineering Education, 42(1), 58-74.

Wallin, P., Gold, J., \& Adawi, T. (2013). Tasting Genuine Research in a Course on Tissue Engineering. In 41th Annual SEFI Conference, Leuven, Belgium.

Wankat, P. C. (2002). The Effective, Efficient Professor: Teaching, Scholarship, and Service. Boston, NJ: Allyn and Bacon.

Yorke, M. (2003). Formative assessment in higher education : Moves towards theory and the enhancement of pedagogic practice. Higher Education, (45), 477-501.

Zimmerman, D. H., \& Wieder, D. L. (1977). The Diary: “Diary-Interview Method.” Urban Life, 5(4), 479-499. 